\title{
INNOVATIVE APPROACH TO MEASURING THE IMPACT OF FDI ON SOME MACROECONOMIC INDICATORS IN B\&H
}

\author{
Slobodan Subotić, Živko Erceg \\ University of East Sarajevo, Faculty of Traffic Engineering Doboj, Bosnia and Herzegovina \\ Vladimir Marković \\ Slobomir P University, Faculty of Economics and Managements, Bosnia and Herzegovina \\ Goran Mitrović \\ Drina insurance company ad Milici, Bosnia and Herzegovina
}

date of paper receipt:

22.03.2018.

Orginal article date of review receipt:

31.03.2018.

UDK: 330.101.54 (497.6)

\section{SUMMARY}

The necessity of economic life and economic development of every economy is the free movement of capital. The international movement of capital has its balance of payment when capital export represents economic surplus in relation to consumption of the national economy and the import of capital represents an increase of consumption in regard to the output of a national economy. Analysis of the influence of foreign direct investment (FDI) on economic growth of the host country, among other things, is emphasized in the function of the achieved phase of its economic development. Taking all this into consideration, the aim of this paper refers to an attempt to indicate the significance and the role of FDI as well as the importance of attracting foreign direct investment in $\mathrm{B} \& \mathrm{H}$ and the determination of the effects of FDI on the economy of $\mathrm{B} \& \mathrm{H}$. In this regard, we will try to determine the level of FDI's impact on some macroeconomic indicators in B\&H (GDP, import, export, unemployment) by using contemporary SPSS statistical analysis program (model) and applying the methods (calculating coefficients) of correlation and regression analysis. In other words, we will determine the analytical expression used to describe a statistical relationship of these macroeconomic categories.

Key words: FDI, macroeconomic indicators, regression and correlation, Bosnia and Herzegovina

\section{INTRODUCTION}

Foreign direct investment (FDI) is the form of international capital flow influencing economic growth of a country and is considered to be an important source of capital whose effects depend on the form and location of investments. Strictly speaking, foreign direct investment implies investment in order to derive profits arising from activities in other countries. The most significant motif of FDI's placement is the profit (expected, long-term capital gain) which is not isolated. It is a complex investor's behavior based on the analysis of the set of parameters in business policy in order to achieve the highest return on investment. In doing so, investors take into account the overall business strategy. It means that, if necessary, they will consciously operate at loss in favor of total profit to ensure the prospects for a long-term increase in profit and the overall prosperity of the company. 


\section{TERM AND MOTIVES OF FOREIGN INVESTMENT}

The realization of foreign investment implies the import of foreign accumulation, which creates the possibility for investments to be higher than domestic accumulations and that increases the rate of economic growth. Reflections of an increased rate of economic growth are visible in a more complete and efficient use of domestic resources. Foreign capital hires domestic labor, that is, it reduces unemployment which is one of the biggest problems in transition countries, including B\&H. FDI has an important impact on economic growth and development of transition countries. Previous experiences show that foreign investment has had a significant role in structural changes of production and import in the countries benefiting from these funds. For countries that have difficult access to the international capital market, FDI represents a "vent" for using foreign assets. Investigated from the temporal perspective, FDI falls into the long-term flow of capital. According to the economic criterion, i.e. long-term movement of capital is realized within the framework of the loan and capital investment. The aims of international movements of long-term capital are determined by the possibilities and needs of investment on an international scale as well as economic and political relations in the world. International capital movement is manifested in two forms. These forms are: 1) portfolio investment and 2) direct investment.

Portfolio investment refers to investing in financial assets. Financial assets which are traded in financial markets usually include: shares, bonds and financial derivatives as derived financial instruments.

Foreign direct investment (FDI) represents an investment in real assets such as manufacturing facilities, property, equipment and so forth. They are related to taking over an existing enterprise, establishing new manufacturing facilities, constructing new factory "on greenfield land" which is called a greenfield investment. However, today the purchase of shares in the amount of 10 percent of the company's value or more is considered to be a direct investment.

FDI has three components: 1) equity capital represents the purchase of a company's shares in one country by a foreign investor; 2) reinvested earnings are earnings based on the possession of the company's shares that are not paid as dividends by a branch office or earnings which are not assigned to a foreign direct investor; 3 ) intra-company loans or intra-company debt transaction are short or long-term loans between a direct investment and a branch office.

Foreign direct investment has two main forms: 1) horizontal and 2) vertical. The horizontal direct investment appears when a company locates manufacturing of the same product or a group of related products in more facilities in different countries. There are three basic methods (ways) of creating these facilities: 1) establishing a new facility (Greenfield operation), 2) purchasing a controlling block of shares of a foreign company which manufactures the same product (acquisition), 3) merging with a foreign company in the same manufacturing group (merger). In this way, multinational companies try to keep secrets of the manufacturing process, management skills and business success under their control.

The vertical foreign direct investment appears when specific operations in the chain of manufacturing and marketing are located in facilities in different countries.

Facilities can be formed in one of the three ways mentioned above (new facilities, purchase and merging). This type of investment is often motivated by the need to secure raw materials abroad for a domestic industry. A characteristic example of vertical investment is the investment of developed countries in mines of underdeveloped countries. 


\section{FOREIGN DIRECT INVESTMENT IN B\&H}

The quantity and quality of investment realized by economic entities are crucial for sustainable economic growth and development. However, retained earnings of enterprises and their own accumulation are often insufficient for major investments. Therefore, an enterprise will find additional external sources of financing. One of the possible sources of investments is foreign direct investment as a special form of financing. Foreign direct investment in the transition countries of Central and Eastern Europe has been shown as a more stable source of financing than any other flow of foreign capital usually without generating debt in a foreign currency.

The special significance of foreign direct investment for Southeastern European countries, including $\mathrm{B} \& \mathrm{H}$, arises from manufacturing and organizational knowledge (know-how) of foreign companies, which is undoubtedly important in the restructuring transition economies intended to develop a more competitive framework. Foreign direct investment plays one of the key roles in creating sustainable economic growth in $\mathrm{B} \& \mathrm{H}$. Hence, foreign direct investment attraction becomes one of the objectives aiming at strengthening the economic sector. Expansion of investment activities would enable an increase of production base which is necessary for generating economic development. Foreign capital attraction would profile national economy through expansion of the product range for export. In fact, it is well known that many investors own chains of distribution and sale of the products that could be made in $\mathrm{B} \& \mathrm{H}$. Foreign direct investment is one of the prerequisites for maintaining and increasing production which would lead to an increase in export.

Except the above mentioned, the foreign investor provides an easier access to other markets. Also, international risk and the country's ranking according to the degree of reforms achieved are positive in correlation with foreign direct investment that a country is able to achieve. Efficiency, height and the structure of investment in B\&H undoubtedly are parameters for successful restructuring and strengthening export competitiveness as well as achieving high growth rates over a longer period of time.

In the case of $\mathrm{B} \& \mathrm{H}$, the FDI inflows were KM 7, 025 billion during the period from 2007 to 2012, while the FDI inflows were KM 2,313 billion in the period of 2009-2012. According to data from Ministry of Foreign Trade and Economic Relations of B\&H, foreign direct investment accounted KM 428, 24 billion in 2011 which represents a decrease of 37,14 compared to 2010 when the total FDI inflow was KM 681, 28 billion. However, during the fourth quarter of 2011, FDI inflows accounted KM 130 billion which is the amount 4,4 times higher comparing to the same period in 2010. Foreign direct investment inflows were KM 430,39 billion and they realized the minimal increase of $0,5 \%$ compared to the year 2011 .

Chart 1 FDI in Bosnia and Herzegovina in the period of 2012-2016 ( mil. KM) ${ }^{1}$

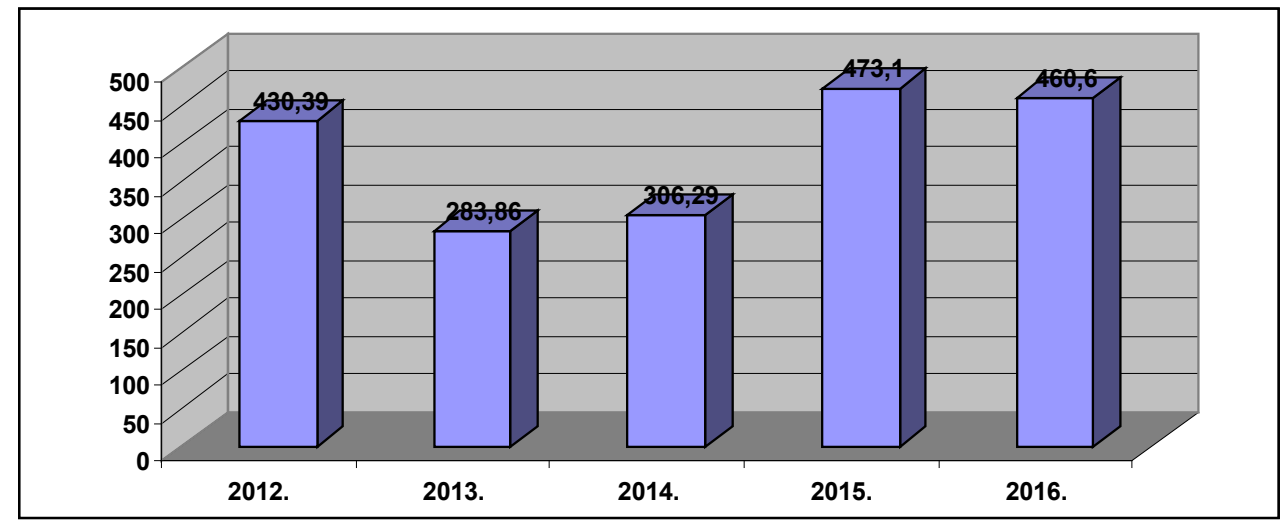

${ }^{1}$ Source: Savjet ministara BiH, Bosna i Hercegovina-Ekonomski trendovi, Godišnji izvještaji 2011-2016. 
The above indicators point to the fact that foreign direct investment (FDI) is characterized by an upward-downward trend line over a five-year period. To be specific, after a slight increase in 2012 compared to 2011, FDI flow declined of 34\%. A slight increase of 8, 13 were accounted next year. A significant growth of FDI flow of 54, $50 \%$ occurred in 2015 comparing to the year 2014. Hence, FDI inflow declined of 2, 64 in 2016.

\section{THE IMPACT OF FDI ON SOME MACROECONOMIC INDICATORS IN B\&H}

Positive results of foreign direct investment inflows should be shown in increasing and changing GDP, manufacturing structure and increasing the employment rate as well. However, foreign direct investment can cause negative consequences to the host economy because of their sector structure. This refers to a decline in employment which is followed by the dismissal of employees due to increased productivity. Movements of some macroeconomic indicators in $\mathrm{B} \& \mathrm{H}$ are presented in the following table.

Table 1 Movements of macroeconomic indicators in B\&H in the period of 2007-2016

\begin{tabular}{|c|r|c|r|r|r|}
\hline Year & $\begin{array}{c}\text { FDI } \\
\text { (mil. } \\
\text { KM) }\end{array}$ & $\begin{array}{l}\text { GDP } \\
\text { (mil. } \\
\text { KM) }\end{array}$ & $\begin{array}{c}\text { Export } \\
(\text { mil. } \\
\text { KM })\end{array}$ & $\begin{array}{c}\text { Import } \\
(\text { mil. } \\
\text { KM })\end{array}$ & $\begin{array}{c}\text { Number of } \\
\text { unemployed } \\
(000)\end{array}$ \\
\hline 2007. & 2.600 & 21.836 & 5.937 & 13.898 & 489 \\
\hline 2008. & 1.337 & 24.759 & 6.712 & 16.293 & 493 \\
\hline 2009. & 352 & 24.051 & 5.530 & 12.348 & 498 \\
\hline 2010. & 431 & 25.886 & 7.532 & 13.005 & 517 \\
\hline 2011. & 428 & 26.798 & 8.403 & 14.637 & 530 \\
\hline 2012. & 430 & 27.308 & 8.483 & 14.635 & 543 \\
\hline 2013. & 284 & 28.027 & 9.037 & 14.496 & 552 \\
\hline 2014. & 306 & 28.189 & 9.299 & 15.477 & 549 \\
\hline 2015. & 473 & 29.462 & 9.884 & 15.216 & 542 \\
\hline 2016. & 461 & 30.389 & 10.587 & 15.636 & 521 \\
\hline
\end{tabular}

In order to achieve correlation between FDI and the observed indicators, it is necessary to apply regression analysis based upon the indicators shown in the table 1. Regression analysis will determine the relationship between the observed variables and it is also necessary to emphasize that simple linear regression will be applied in order to determine individual relationships and conclusions between FDI and GDP from one side and export, import and unemployment from another.

Table 2 Coefficients of determination between variables GDP-FDI

\begin{tabular}{|c|r|c|c|c|}
\hline \multicolumn{6}{|c|}{ Model Summary } \\
\hline Model & R & R Square & Adjusted R Square & $\begin{array}{c}\text { Std. Error of the } \\
\text { Estimate }\end{array}$ \\
\hline 1 & \multicolumn{6}{|c|}{$.714^{\mathrm{a}}$} & \multicolumn{5}{|c|}{ a. Predictors: (Constant), FDI } & 1929.13242 \\
\hline
\end{tabular}

The table 2 shows the relationship between GDP as the dependent variable and FDI as the independent one. The results reveal that $50,9 \%$ of GDP variance is explained by FDI variance, that is , 50,9\% of GDP variable is determined by FDI variable. Based on the data obtained by the F-test $(\mathrm{F}=8,308$; $\mathrm{p}$ value $=0,02)$, it can be concluded that the relationship between FDI and GDP

\footnotetext{
${ }^{2}$ Source : Savjet ministara BiH, Bosna i Hercegovina-Ekonomski trendovi, Godišnji izvještaji 2007-2016.
} 
is statistically significant, that is, the obtained coefficient of determination is not a coincidence because FDI can be statistically significant indicator in estimating the level of GDP in the years ahead.

Table 3 Indicators of regression analysis (GDP-FDI)

\begin{tabular}{|c|c|c|c|c|c|c|}
\hline \multicolumn{7}{|c|}{ Coefficients $\mathrm{a}^{\mathrm{a}}$} \\
\hline \multirow{2}{*}{\multicolumn{2}{|c|}{ Model }} & \multicolumn{2}{|c|}{$\begin{array}{l}\text { Unstandardized } \\
\text { Coefficients }\end{array}$} & \multirow{2}{*}{$\begin{array}{c}\text { Standardized } \\
\text { Coefficients } \\
\text { Beta }\end{array}$} & \multirow[t]{2}{*}{$\mathrm{t}$} & \multirow[t]{2}{*}{ Sig. } \\
\hline & & $\mathrm{B}$ & Std. Error & & & \\
\hline \multirow{2}{*}{1} & (Constant) & 28474.500 & 873.995 & & 32.580 & .000 \\
\hline & SDI & -2.540 & .881 & -.714 & -2.882 & .020 \\
\hline
\end{tabular}

The obtained coefficient B or $\beta$ indicates in which way and how string the independent variable affects the dependent one and accordingly, we get the equation of regression which shows that the increase of FDI of one million results in a GDP reduction of KM 2, 54 million.

$$
\mathrm{Y}=28474,50-2,5401^{\star} \mathrm{X} 1
$$

Table 4 Indicators of regression analysis ( import-FDI)

\begin{tabular}{|c|c|c|c|c|}
\hline \multicolumn{5}{|c|}{ Model Summary } \\
\hline Model & $\mathrm{R}$ & $\begin{array}{c}\mathrm{R} \\
\text { Square }\end{array}$ & $\begin{array}{c}\text { Adjusted R } \\
\text { Square }\end{array}$ & $\begin{array}{c}\text { Std. Error of } \\
\text { the Estimate }\end{array}$ \\
\hline 1 & $.543^{\mathrm{a}}$ & .295 & .207 & 1497.08886 \\
\hline \multicolumn{5}{|c|}{ a. Predictors: (Constant), FDI } \\
\hline
\end{tabular}

According to obtained data in the table 4, it can be concluded that $29,5 \%$ of the variation of the dependent export is determined by the variation of the dependent FDI. Further analysis and results of F-test $(\mathrm{F}=3,35 ; \mathrm{p}$ value $=0,105)$ indicate that given indicators, coefficient of determination $\mathrm{R} 2$ and $\mathrm{B}$, that is $\beta$, are not statistically significant and we can conclude that FDI as the independent variable cannot be an adequate indicator in terms of export.

Table 5 Indicators of regression analysis ( export-FDI)

\begin{tabular}{|c|c|c|c|c|c|c|}
\hline \multicolumn{7}{|c|}{ Coefficients $^{\mathrm{a}}$} \\
\hline & \multirow[t]{2}{*}{ Model } & \multicolumn{2}{|c|}{$\begin{array}{l}\text { Unstandardized } \\
\text { Coefficients }\end{array}$} & \multirow{2}{*}{$\begin{array}{c}\text { Standardized } \\
\text { Coefficients }\end{array}$} & \multirow[t]{2}{*}{$\mathrm{t}$} & \multirow[t]{2}{*}{ Sig. } \\
\hline & & B & Std. Error & & & \\
\hline \multirow{2}{*}{1} & (Constant) & 9029.363 & 678.257 & & 13.313 & .000 \\
\hline & SDI & -1.252 & .684 & -.543 & -1.830 & .105 \\
\hline \multicolumn{7}{|c|}{ a. Dependent Variable: EXPORT } \\
\hline
\end{tabular}

The equation of regression given in this analysis, as in previous case, shows that the increase of FDI results in reduction of the export level in $\mathrm{B} \& \mathrm{H}$.

$$
\mathrm{Y}=9029,363-1,252^{\star} \mathrm{X} 1
$$


Table 6 Coefficients of determination between variables export-FDI

\begin{tabular}{|c|c|c|c|c|}
\hline \multicolumn{5}{|c|}{ Model Summary } \\
\hline Model & $\mathrm{R}$ & $\begin{array}{c}\mathrm{R} \\
\text { Square }\end{array}$ & $\begin{array}{c}\text { Adjusted R } \\
\text { Square }\end{array}$ & $\begin{array}{c}\text { Std. Error of the } \\
\text { Estimate }\end{array}$ \\
\hline 1 & $.032^{\mathrm{a}}$ & .001 & -.124 & 1283.73239 \\
\hline \multicolumn{5}{|c|}{ a. Predictors: (Constant), FDI } \\
\hline
\end{tabular}

By analyzing the relationship between FDI and export, based on the obtained results in the table 6 , we can conclude that there is no relationship between observed dependents. Namely, only $0,1 \%$ of the variable export can be explained by variations of FDI . To be more specific, every change of FDI affects changes in export only by $0,1 \%$. Consequently, it was expected that there is no statistical significance of the relationship between these variables as evidenced by results of F-test $(F=0,008)$, while the $p$ value is 0,931 , which is significantly higher than the significance level $\alpha=0,05$.

Table 7 Indicators of regression analysis ( import-FDI)

\begin{tabular}{|c|c|c|c|c|c|c|}
\hline \multicolumn{7}{|c|}{ Coefficients $^{\mathrm{a}}$} \\
\hline \multirow{2}{*}{\multicolumn{2}{|c|}{ Model }} & \multicolumn{2}{|c|}{$\begin{array}{l}\text { Unstandardized } \\
\text { Coefficients }\end{array}$} & \multirow{3}{*}{$\begin{array}{c}\text { Standardized } \\
\text { Coefficients }\end{array}$} & \multirow[t]{2}{*}{$\mathrm{t}$} & \multirow[t]{2}{*}{ Sig. } \\
\hline & & B & Std. Error & & & \\
\hline \multirow{2}{*}{1} & (Constant) & 14526.778 & 581.596 & & 24.977 & .000 \\
\hline & SDI & .053 & .586 & .032 & .090 & .931 \\
\hline \multicolumn{7}{|c|}{ a. Dependent Variable: IMPORT } \\
\hline
\end{tabular}

The relationship between variables is not statistically significant; it is clear that the obtained coefficients $B$, that is $\beta$, are not statistically significant $(t=0.90 ; p$ value 0.931$)$, and we cannot consider the SDI variable as an adequate predictor of import variable.

Table 8 Coefficients of determination between variables unemployment-FDI

\begin{tabular}{|c|c|c|c|r|}
\hline \multicolumn{5}{|c|}{ Model Summary } \\
\hline Model & $\mathrm{R}$ & $\begin{array}{c}\mathrm{R} \\
\text { Square }\end{array}$ & $\begin{array}{c}\text { Adjusted R } \\
\text { Square }\end{array}$ & $\begin{array}{c}\text { Std. Error of } \\
\text { the Estimate }\end{array}$ \\
\hline 1 & $.687^{\mathrm{a}}$ & .472 & .406 & 18.24283 \\
\hline \multicolumn{5}{|c|}{ a. Predictors: (Constant), FDI } \\
\hline
\end{tabular}

The last relationship analyzed relates to SDI and unemployment. The model shows that $47.2 \%$ of variability of dependent unemployment is determined by variations of the variable SDI. Given the $\mathrm{F}$ test results $(\mathrm{F}=7,163$; $\mathrm{p}$ value $=0,028)$ this indicator can be considered statistically significant. 
Table 9 Indicators of regression analysis ( unemployment-SDI)

\begin{tabular}{|c|c|c|c|c|c|c|}
\hline \multicolumn{7}{|c|}{ Coefficients $^{\mathrm{a}}$} \\
\hline \multirow{2}{*}{\multicolumn{2}{|c|}{ Model }} & \multicolumn{2}{|c|}{$\begin{array}{l}\text { Unstandardized } \\
\text { Coefficients }\end{array}$} & \multirow{2}{*}{$\begin{array}{c}\text { Standardized } \\
\text { Coefficients } \\
\text { Beta }\end{array}$} & \multirow[t]{2}{*}{$\mathrm{t}$} & \multirow[t]{2}{*}{ Sig. } \\
\hline & & B & Std. Error & & & \\
\hline \multirow{2}{*}{1} & (Constant) & 539.241 & 8.265 & & 65.244 & .000 \\
\hline & SDI & -.022 & .008 & -.687 & -2.676 & .028 \\
\hline
\end{tabular}

Statistical significance indicates that the relationship between the dependent variables is not accidental, but that there is a certain legitimate relationship that is represented by the equation of regression. In this analysis, the equation of regression is formed on the basis of the coefficient $\mathrm{B}$, and it follows:

$$
\mathrm{Y}=539,241-0,022^{\star} \mathrm{X} 1
$$

This equation of regression suggests that the growth of FDI in B\&H will lead to a reduction in unemployment.

In order to complete the analysis and gain a better insight into the relationship between observed variables, except regression analysis, it was necessary to do a correlation analysis which will provide information on the strength and the way of matching certain variables. Before joining the correlation coefficient calculation, a check of the normality of the observed data positions was made by using the 3B Stat statistical package, and it was concluded that all variables do not have a normal position This conclusion pointed to the need to calculate Spearman's coefficient of correlation (rho). In the following table are given all calculated Spearman's correlation coefficients.

Table 10 Correlation coefficients of variables

\begin{tabular}{|c|c|c|c|c|c|c|c|}
\hline \multicolumn{8}{|c|}{ Correlations } \\
\hline & & & FDI & GDP & EXPORT & IMPORT & $\begin{array}{l}\text { NUMBER } \\
\text { OF UNEM- } \\
\text { PLOYED }\end{array}$ \\
\hline \multirow{15}{*}{$\begin{array}{c}\text { Spearman's } \\
\text { rho }\end{array}$} & \multirow{3}{*}{ FDI } & $\begin{array}{l}\text { Correlation } \\
\text { Coefficient }\end{array}$ & 1.000 & -.248 & -.164 & .248 & $-.709^{*}$ \\
\hline & & Sig. (2-tailed) & 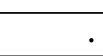 & .489 & .651 & .489 & .022 \\
\hline & & $\mathrm{N}$ & 10 & 10 & 10 & 10 & 10 \\
\hline & \multirow{3}{*}{ GDP } & $\begin{array}{l}\text { Correlation } \\
\text { Coefficient }\end{array}$ & -.248 & 1.000 & $.988^{* *}$ & .552 & $.721^{*}$ \\
\hline & & Sig. (2-tailed) & .489 & & .000 & .098 & .019 \\
\hline & & $\mathrm{N}$ & 10 & 10 & 10 & 10 & 10 \\
\hline & \multirow{3}{*}{ EXPORT } & $\begin{array}{l}\text { Correlation } \\
\text { Coefficient }\end{array}$ & -.164 & $.988^{* *}$ & 1.000 & .576 & $.697^{*}$ \\
\hline & & Sig. (2-tailed) & .651 & .000 & 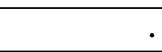 & .082 & .025 \\
\hline & & $\mathrm{N}$ & 10 & 10 & 10 & 10 & 10 \\
\hline & \multirow{3}{*}{ IMPORT } & $\begin{array}{l}\text { Correlation } \\
\text { Coefficient }\end{array}$ & 248 & .552 & .576 & 1.000 & .164 \\
\hline & & Sig. (2-tailed) & .489 & .098 & .082 & . & .651 \\
\hline & & $\mathrm{N}$ & 10 & 10 & 10 & 10 & 10 \\
\hline & \multirow{3}{*}{$\begin{array}{l}\text { NUMBER OF } \\
\text { UNEMPLOYED }\end{array}$} & $\begin{array}{l}\text { Correlation } \\
\text { Coefficient }\end{array}$ & $-.709^{*}$ & $.721^{*}$ & $.697^{*}$ & .164 & 1.000 \\
\hline & & Sig. (2-tailed) & .022 & .019 & .025 & .651 & \\
\hline & & $\mathrm{N}$ & 10 & 10 & 10 & 10 & 10 \\
\hline
\end{tabular}


From the data presented in the above table, it is evident that FDI is in the strongest correlation with unemployment $($ rho $=-0,709)$ and that this relationship is indirect, i.e. that with the growth of FDI there is a decrease in unemployment. The obtained data also indicate that this correlation coefficient is statistically significant. The data indicate that the relationship with GDP and imports of identical strength ( $r h o=0,248)$, but with different indications, which lead to the conclusion that with SDI growth there is a decrease in GDP and an increase in imports. The correlation coefficient between GDP and imports is positive, and it implies that there is a direct relationship between these variables, which is not statistically significant. On the other hand, the coefficient of GDP and export correlation is extremely high $(\mathrm{rho}=0.988)$ and its sign indicates that GDP growth indicates growth of $\mathrm{B} \& \mathrm{H}$ exports. The relationship between exports and imports is direct, but not statistically significant, while the rho correlation coefficient is 0.576 . Also, the relationship between exports and unemployment is direct, but statistically significant $(\mathrm{rho}=0.697)$.

\section{CONCLUSION}

Foreign direct investment has one of the key roles in creating self-sustaining economic growth in Bosnia and Herzegovina. Foreign direct investment in Bosnia and Herzegovina amounted KM 7,025 billion in the period from 2007 to 2012, while foreign direct investments in the four-year period (2009-2012) amounted KM 2,313 billion. However, Bosnia and Herzegovina has not been spared the impact of the global financial crisis, the consequences of which are, above all, visible in the real sector of the economy. Apart from having a negative impact on the financial and real sector, the global financial crisis has left a visible mark on the inflow of foreign direct investment in Bosnia and Herzegovina. Domestic factors such as slowed down economic growth and reduced inflows of foreign direct investment also contributed to economic instability in Bosnia and Herzegovina. In addition to weak domestic demand, unfavorable external environment and political stalemate, the poor performance of the macroeconomic, business and legal environment halted the economic recovery of Bosnia and Herzegovina.

The obtained results of the regression analysis relate to the strength, direction and statistical significance of the relationships between the observed variables. In this regard, regression analysis indicates that there is a statistically significant relationship between FDI and GDP, as well as the link between FDI and unemployment. The obtained regression equations point to the conclusion that with SDI growth there is a decrease in GDP, which is not logical. In addition, the correlation coefficient obtained (rho $=-0,248$ ) is also indicated. This illogical picture can partly be explained by the extremely high FDI amounts in the first two years observed, which due to the low development of the economy in B\&H, failed to follow the adequate level of GDP. This is supported by the fact that if two years were excluded from the analysis, the correlation coefficient would have been positive and would indicate that FDI growth corresponds to GDP growth. In contrast, the obtained equation of regression between FDI and unemployment indicates that the growth of FDI results in a decrease in unemployment. This claim goes to the value of the correlation coefficient obtained $($ rho $=0.709)$. A further analysis of the correlation coefficient suggests that GDP growth did not contribute to the creation of new jobs and recruitment of labor, but some other factors. This means that with the growth of exports there was no significant development of the economy and the creation of new jobs. 


\section{REFERENCES}

Kovačević Radovan: Oblici i mehanizmi stranih ulaganja, Ekspertsko savjetovanje-Strana ulaganja, Univerzitet "Braća Karic'" Beograd, mart 2000.

Kovačević Radovan:Međunarodne finansije, Beograd, 2011.

Savjet ministara BiH, Bosna i Hercegovina-Ekonomski trendovi, Godišnji izvještaji 2007-2016.

Savjet ministara BiH, Bosna i Hercegovina-Ekonomski trendovi, Godišnji izvještaj 2012., Sarajevo, april 2013.

Savjet ministara BiH, Bosna i Hercegovina-Ekonomski trendovi, Godišnji izvještaji 2011-2016.

Strana ulaganja, Uneverzitet 'Braća Karić", Beograd, mart 2000. MIGA Annual report, World Bank Group, Washington, 2009.

Vlada Republike Srpske, Ekonomska politika Republike Srpske za 2012.godinu, Banja Luka, decembar 2011.

Agencija za statistiku $\mathrm{BiH}$ (www.bhas.ba)

Centralna banka $\mathrm{BiH}$ (www.cbbh.ba) 